\title{
8 \\ HINDU NATIONALIST STATECRAFT AND MODI'S AUTHORITARIAN POPULISM
}

\author{
Kenneth Bo Nielsen and Alf Gunvald Nilsen
}

Political scientists have rightly considered the government of the right-wing Hindu nationalist Bharatiya Janata Party (BJP) under Prime Minister Narendra Modi, which first came to power in the 2014 general election and then consolidated its position in the subsequent general election in 2019, as constituting a watershed in the political life of the Indian republic. Milan Vaishnav and Jamie Hintson (2019) argue that the 2019 elections ushered in India's fourth dominant party system, centred on the BJP and its politics. Christophe Jaffrelot and Gilles Verniers (2020: 143) go further, and argue that the 2019 elections brought about a new political system, as Modi 2.0 has "radically changed gears and used the legislative and executive route to transform India into a de jure ethnic democracy" (see also Nilsen, Nielsen and Vaidya 2022). "Indeed", Achin Vanaik (2017: 29) writes, "the scale of BJP hegemony today can bear comparison to that of the Indian National Congress party in the first decades after Independence, under Jawaharlal Nehru and his daughter, Indira Gandhi."

But how do we explain the politics of this new hegemonic order in India? In this chapter, we focus on how Modi's authoritarian populism has come, increasingly, to mobilize the law in order to align the nation with the core tenets of Hindu nationalism. We see Modi's authoritarian populism as a form of conservative politics that constructs a contradiction between common people and elites, and then uses this contradiction to justify the imposition of repressive measures by the state (Hall 1988). We also see it, crucially, as a populism that draws a line between "true Indians" and their "anti-national" enemies, and subjects the latter to coercion in order, supposedly, to protect the former (Müller 2016). In line with the core tenets of Hindu nationalism, this line is defined in large part by religion - the ominous Other that authoritarian populism depends on in order to frame a unitary conception of the nation and national culture is, in Modi's India, the Muslim (see Nilsen 2021a, 2021b). In this chapter, we analyze how this religiously defined dividing line is being codified into law in order to align the nation with the core tenets of Hindu nationalism. We refer to this particular enactment of the BJP's political agenda as Hindu nationalist statecraft - that is, as a strategy centred on legally locking in claims that India is and should be a Hindu rashtra in ways that make it exceedingly difficult to reverse such claims in the future (see Nilsen 2020). In the hegemonic project of the BJP and the wider Hindu nationalist movement, we argue, this strategy allows religious majoritarianism to dictate law-making and override the precepts of secular constitutional morality, as well as the general democratic principle of protecting minority rights. Always-already conjoined with majoritarian 
violence, Hindu nationalist statecraft arguably poses the most serious threat that India's secular, constitutional democracy has faced since its inception at independence in 1947.

\section{The BJP from Ayodhya to Modi}

The BJP first entered the arena of Indian politics as a minor player in 1980, when former members of the Bharatiya Jana Sangh, the political arm of the Hindu nationalist movement from the early 1950s to the late 1970s, established the party in order, as Christophe Jaffrelot (1996: 315) puts it, "to inherit the mantle of the Janata party" that had ruled India from 1977 to 1980 . Furthermore, this would require a relative side-lining of Hindu nationalism vis-à-vis socioeconomic interests, reliance on political leaders that could appeal to group and sectional interests rather than on ideologues, and a readiness to enter into electoral alliances with mainstream political parties (ibid.: 315). However, it was not moderation that would propel the BJP from the status of a minor player to a force to be reckoned with in Indian politics - it was, rather, spectacular collective violence that drove this process.

In 1990, India was on the cusp of a dramatic political convulsion that unsettled the castebased power relations that had prevailed since independence in 1947. In response to increasingly militant demands from below, the central government - a coalition of non-Congress parties known as the National Front, with outside support from the BJP - introduced a comprehensive scheme of affirmative action, granting reservations of 27 per cent of all jobs in the public sector to lower caste groups, the so-called Other Backward Classes. This caused uproar among India's middle classes and upper castes - the very same groups who constituted the core constituency of the BJP (see Hansen 1999). Responding to these developments, the BJP president Lal Krishna Advani launched a rath yatra - a chariot procession - that was to make its way across India to Ayodhya to lay claim to the disputed site of the Babri Masjid, a sixteenth-century mosque that, according to Hindu nationalist claims, had been erected on the birthplace of the Hindu deity Lord Ram. In doing so, Advani and other prominent BJP politicians aligned themselves decisively with the Ram Janmabhoomi (literally, birthplace of Ram) movement of the Vishva Hindu Parishad (World Hindu Council) - a central node in the vast network of the Hindu nationalist movement - and its demand that the Babri Masjid should make way for a Ram temple. Advani's goal was obvious, namely to shore up and consolidate middle class and upper caste support for his party (Hansen 1999; Jaffrelot 1996: chapters 12 and 13).

Beginning in late September 1990, Advani's yatra mobilized thousands of volunteers among them Narendra Modi, who at that point in time was a prominent Hindu nationalist activist - and crossed through hundreds of towns and villages. Deploying hard-line religious symbolism, the procession sparked violent communal riots, and Advani was finally arrested in late October as he attempted to cross into the state of Uttar Pradesh. Despite Advani's arrest, large numbers of Hindu nationalist activists - estimates range between 40,000 and 75,000 made their way to Ayodhya and laid siege to the Babri Masjid until they were dispersed after three days of running battles with security forces (Nilsen 2019). This, however, was not the end of the movement for a Ram temple in Ayodhya. On the contrary, in early December 1992, the Rashtriya Swayamsevak Sangh (RSS) - the ideological backbone of the Hindu nationalist movement - organized a rally that attracted about 150,000 kar sevaks (activist volunteers) to the site of the Babri Masjid. After speeches by Advani and other central BJP politicians, the crowd attacked the mosque and demolished it. The destruction of the mosque sparked new rounds of communal violence, in which more than 2,000 people - the majority of whom were Muslims were killed (see Hasan 2014: chapter 1). 
Whereas the demolition was a tragedy for India's Muslim citizens, it was a successful strategic move on the part of the BJP, which had withdrawn its support from the National Front government after the violent end of the rath yatra. In the general elections that ensued in 1991, the party, which had now firmly established itself as a defender of Hindu values and interests in a changing nation, won 120 seats - up from 85 seats in the 1989 elections. And by the end of the 1990s - a decade that witnessed deepening communal polarization - the BJP found itself for the first time at the head of a national coalition government and decisively established as a force to be reckoned with in Indian politics (Hasan 2014: chapter 1). In other words, Advani's ploy to galvanize electoral support through religious mythology and violence paid off, and as such it constitutes a crucial prehistory to today's political scenario in India, in which the BJP under Modi rules supreme.

\section{The Emergence of Modi's Authoritarian Populism}

Modi's rise to first regional and later national power was similarly lubricated by the kind of majoritarian collective violence that characterized Hindu nationalist politics in the 1980s and 1990s. Modi's trajectory began at an early age in the Rashtriya Swayamsewak Sangh (RSS) and only shifted to the BJP in the late 1980s. In the BJP, he played an important organizational role in the series of marches that mobilized youth towards anti-Muslim violence, and which culminated in the demolition of the Babri Masjid. Indeed, Modi has been described as Advani's "navigator" in his 1990 yatra (Kanungo 2019).

A decade later, Modi was installed as Chief Minister of Gujarat in 2001 to stabilize the BJP at a time of crisis. He had an unremarkable and not particularly popular term until events provided him with another opportunity to further Hindu nationalist politics by deploying extra-legal violence against minorities. In February 2002, a number of Hindu pilgrims were killed in a fire inside the Sabarmati Express train at Godhra station in Gujarat. Shortly afterwards, highly organized Hindu nationalist mobs who blamed Muslims for setting the train on fire unleashed an unprecedented anti-Muslim pogrom and attacked Muslim homes, neighbourhoods and businesses, killing hundreds, if not thousands, of Muslims. After three days of silence during which violent Hindutva activists largely had a free run, Modi spoke only to apparently defend the perpetrators by calling the pogrom a svabhavik patrikriya, a natural reaction (GhassemFachandi 2019). Modi's association with the violence allowed him to reap electoral gains in successive state elections, to increase his grip over the state machinery and civil society (Shani 2007; Basu 2015; Berenschot 2011), and even to establish a relatively independent position vis-à-vis the powerful RSS.

Between the anti-Muslim pogroms of 2002 and his ascension to the pinnacle of national political power in 2014, Modi was reinvented as a market-friendly technocrat and primary architect of Gujarat's supposed development miracle (see Bobbio 2012, 2013; Sud 2012, 2020). This was the image that was front and centre of the BJP's campaign for the 2014 general election: Modi was portrayed as vikas purush - a man of development who would extend the scope of the Gujarat miracle to the Indian nation (Nilsen 2021a, 2021b). However, although its articulation was more subdued, Hindu nationalism was never absent from the BJP campaign trail in 2013-2014, and after the elections it became more and more central to the party's agenda (Kaul 2017). A majoritarian cultural politics crystallized around issues such as cow protection, the communal policing of interreligious love and of women's sexuality, the rewriting of school textbooks to bring them in line with Hindutva historiography, and the promotion of religious reconversion among Muslims and Christians (see Flåten 2016; Basu 2015). Hate speech has proliferated, and majoritarian rhetoric is clearly linked to communal violence against 


\section{Hindu nationalist statecraft}

Muslims and other marginal groups, such as Dalits. In fact, it was recently estimated that more than 86 per cent of all vigilante attacks on Muslims and Dalits since 2009 had taken place under Modi's premiership (Abraham and Rao 2017).

Following the general election in 2019, this majoritarian violence has become intertwined with a systematic effort on the part of the government to write Hindu nationalist ideology into law in a way that is unprecedented in postcolonial India. Indeed, the 2019 election marks a point of transition in Hindutva politics under Modi. As argued in this section, during Modi's first term in power, the majoritarian cultural nationalism that draws a line between "true Indians" and their enemies, and seeks to rally popular support for a crackdown on those enemies, was predominantly pursued through the vigilante violence of Hindu nationalist mobs. However, with the onset of Modi's second term in power, we are witnessing an increased recourse to the law to further advance the project of turning India into a Hindu rashtra. It is this effort - the locking in of Hindu nationalist claims to the nation into law - that we refer to as Hindu nationalist statecraft, and to which we turn below.

\section{The Politics of Hindu nationalist statecraft}

In August 2019, the Modi government revoked Kashmir's special constitutional status, relegating what was then India's only Muslim-majority state to a union territory. The abolition of Kashmir's statehood was an act of territorial engineering designed to advance the idea of a Hindu rashtra in very tangible ways. Not only did it set the stage for an onslaught against insurgent citizens who are overwhelmingly Muslim, it also cleared the ground for changing the demography of the state. The revocation of Kashmir's special constitutional status means that Kashmiri authorities no longer have the right to define who is a permanent resident with a right to own land in the state. This created the possibility of changing the make-up of its population to such an extent that the aspiration among Kashmir's Muslim-majority population for genuine freedom - for azaadi - would be rendered completely impossible (Nilsen 2020). As journalist Haris Zargar (2020a, 2020b) has noted, the subsequent introduction of new domicile land laws that discriminate in multiple ways against Kashmiris goes a long way towards reducing Kashmir to a settler-colony of India and its Hindu majority. Indeed, as argued by Partha Chatterjee (2019), Kashmir may well be seen as the BJP's laboratory for "developing the constitutional rules of internal colonialism". The symbolic politics of these legislative moves is abundantly clear: the Hindu nation is to be built by purging India's territory of the Muslim enemy within (see Nilsen, Nielsen and Vaidya 2022). But it may not stop there. As Chatterjee (2019) warns, the thrust of the majoritarian logic of Hindu nationalist statecraft nationalism may hit every minority - whether based on language, religion, caste, or gender - that appears to stand in the way of a homogeneous nationhood.

Subsequently, in November 2019, India's Supreme Court passed its verdict in the Ayodhya dispute, in favour of Hindu plaintiffs who claimed the right to the land where the Babri Masjid stood until its demolition in December 1992. In doing so, the Supreme Court lent credence to Hindu nationalist mythology which claims that this land is the birthplace of Lord Ram, and therefore rightfully belongs to India's Hindu majority. The verdict is troubling in itself. But even more worrisome, the verdict signalled that the Supreme Court, which is supposed to be an independent guardian of India's secular constitutional democracy, and which had been hailed since the Emergency as the last resort of the oppressed and the bewildered (Baxi 1985), had now been rendered increasingly "timid, tentative, fragmented and vulnerable, wary of hurting the central executive" led by Modi - who, tellingly, was the key speaker at the temple's ground-breaking ceremony held less than a year later (see Sebastian 2019). In fact, the 
trend for the Supreme Court to align itself with the political agenda of the Modi regime has intensified both prior to and after the Ayodhya verdict. This can be seen, on the one hand, in its non-confrontational stance on consequential legal interventions, including the abrogation of Article 370, and the Citizen Amendment Act and National Registry of Citizens that we turn to below; and, on the other hand, in the growing tendency - also prevalent in the lower courts - of citing "the national interest" to legalize the violation of citizens' rights, thus tilting "the scales of justice... against those opposed to the Modi government" (Chhibber 2020). This, Jaffrelot (2020a) argued in late 2020, marks a striking departure from business as usual: "over the last four years, none of [the Supreme Court's] decisions has come as a major embarrassment for the government. For these two power centres to be on the same wavelength for such a long time is unprecedented." One expert on the Indian Supreme Court sees in this "the complete capitulation of the Supreme Court to the majoritarian rule of Prime Minister Narendra Modi", reducing it to "a cheerleader for the Modi government's agenda" (Bhuwania 2020).

The Ayodhya judgment, in turn, was followed in early December 2019 by the passing into law of the Citizenship Amendment Act (CAA), mentioned above. The CAA offers expedited citizenship for persecuted religious minorities from India's Muslim-majority neighbouring countries Afghanistan, Pakistan, and Bangladesh who can prove that they have been living in India since before 31 December 2014. However, the CAA only extends this right to Hindus, Christians, Sikhs, Buddhists, Jains, and Parsis, but not to persecuted Muslims in these countries, such as the Ahmadis in Pakistan or the Hazaras in Afghanistan. Similarly, persecuted religious minorities from other neighbouring countries such as Nepal, Sri Lanka or Myanmar cannot avail of the offer of expedited citizenship.

The CAA will work in tandem with a national population register and a National Registry of Citizens (NRC) under which the right to Indian citizenship is directly linked to whether or not individuals can prove that they were born in India between January 1950 and June 1987, or that they are children of bona fide Indian citizens. As people often do not have the kind of documents required by this process, many risk losing their citizenship. However, Hindus who find themselves in this situation can resort to the lifeline offered by the CAA. Given that this opportunity is not afforded to Muslims, the CAA - NRC couplet is likely to create a hierarchy of citizenship graded along religious lines, in which Indian Muslims end up as second-class citizens (Nilsen 2020).

While the politics of Hindu nationalist statecraft is crucially enacted by the national government, the division of legislative powers between the national parliament and the state assemblies means that Hindu nationalist statecraft increasingly also animates law-making at the level of the federal states - especially in states where the BJP is in power. One example of this is cow protection, which falls within states' competence, and the related laws that have been introduced towards this end in different states since Modi came to power in 2014. Cow protection as a tactic to assert Hindu identity has deep roots among Hindu reform groups from the latter half of the nineteenth century, and was one of the core issues of the BJP's predecessor, the BJS, immediately after independence. Under Modi, it has acquired a renewed urgency. Modi is known to favour a national ban on cow slaughter (Andersen and Damle 2019: 179), but has so far not initiated the constitutional changes that would enable a national government to legislate on this issue. Instead, state-level legislative changes have systematically made the slaughter of cows or even the sale and possession of cow beef illegal in ever-larger parts of the country under Modi's tenure (Jaffrelot 2019: 59). Modi's home state of Gujarat, for instance, in 2017, amended an act from 1954 that criminalized cow slaughter, transportation of cows for slaughter, and the possession of beef, to extend the maximum sentence for cow slaughter to life imprisonment. Other BJP-controlled states such as Maharashtra (where BJP was ousted from office in late 
2019) and Haryana have also toughened cow protection legislation by criminalizing beef consumption in 2015. The former has imposed a total ban on the slaughter of all cattle (bulls and bullocks included) and has completely banned all transport of cattle out of the state (Ramdas 2017), while in the latter, the state police has set up a "cow task force" (Jaffrelot 2019: 62). And Uttar Pradesh, under the hard-line Hindu nationalist chief minister Yogi Adityanath, recently imposed unprecedentedly strict legal punishments for various offences ranging from cow slaughter to "endangering the life of cows" by, for example, not providing them food and water. The Adityanath government is also known to publish the name and photograph of people accused of breaking the state Cow Slaughter Act if they try to evade the law enforcement agencies (Lalchandani 2020). Uttar Pradesh, along with Gujarat and Rajasthan, also recently introduced legal amendments enabling the confiscation of vehicles alleged to be transporting cattle for slaughter (Ramdas 2020). The southern state of Karnataka - ruled by the BJP since 2019 - followed suit in 2020 by passing the Prevention of Slaughter and Preservation of Cattle Bill, 2020, a bill that not only bans the slaughter of all cows, bulls, bullocks and calves, but also outlaws the slaughter of buffaloes below the age of thirteen, makes smuggling and transporting animals for slaughter an offence and empowers the police to conduct searches based on suspicion (Daniyal 2020).

These laws advance the project of Hindu nationalist statecraft in three interrelated ways. Most immediately, they criminalize the activities of entire beef eating communities, particularly Muslims but also Dalits and Christians, and render everyday social, culinary and economic activities illegal. Second, this enhanced legal protection for the cow and higher sentences for offenders boosts Hindu nationalist cow protection vigilantes, who now feel that their violent actions are backed by the letter of the law and endorsed by the governments that passed them. Again, the victims of such violence are invariably Muslims (but also Dalits) accused of killing and eating cows or illegally transporting them for slaughter. Such violent "Islamophobic gastronomy", Raj Patel (2018) argues, is in effect a way of adjudicating over citizenship that is becoming increasingly widespread within authoritarian populist regimes. Lastly, the consequences of the legal crackdown on beef have, in economic terms, hit Muslims and Dalits the hardest (Jakobsen and Nielsen 2021).

Another example of how Hindu nationalist statecraft that animates law-making at the level of the federal states is the recent introduction of laws by the Yogi Adityanath government in the state of Uttar Pradesh to prevent so-called love jihad. "Love jihad" is an Islamophobic conspiracy theory centred on the false claim that Muslim men marry Hindu women in order to force them to convert to Islam (Zargar 2020c). The Uttar Pradesh Prohibition of Unlawful Conversion of Religion Ordinance, which was passed into law in late November 2020, effectively criminalizes interfaith marriages, and in doing so it extends Hindu nationalist statecraft into the intimate domain. Several other BJP-ruled states such as Madhya Pradesh and Haryana have signalled their intention to introduce similar legislation. Based on the ideological construct of the Muslim man as a malevolent predator and the Hindu woman as a passive victim in need of patriarchal protection - a construct that has historically been foundational to Hindutva politics - the law echoes the foundational logic of Modi's authoritarian populism, in which Muslims constitute an enemy within that must be defeated to guard the sanctity of the Hindu nation (Gupta 2021). Much like the case of cow protection laws, the Uttar Pradesh legislation against "love jihad" illustrates the proximity between Hindu nationalist statecraft and extra-legal majoritarian violence. The policing of interfaith relationships has been a staple activity among Hindu nationalist vigilante groups under Modi - indeed, as Jaffrelot (2020b) has commented, in promulgating this law, the $\mathrm{BJP}$-controlled state apparatus is picking up the baton from these vigilante groups (see also Chowdhury 2020). 


\section{Concluding remarks}

There can be little doubt that India today is in the throes of a dramatic process of autocratization. Key pillars of the secular democratic order that came into being in 1947 are being eroded, and the driving force of that erosion is the politics of the Modi regime.

In this chapter, we have focused on the role that law and law-making has come to play in advancing a hegemonic project of authoritarian populism centred on a distinction between "true Indians" and their "anti-national enemies" within, embodied by Indian Muslims along with dissenters. Since Modi's re-election in 2019, India's BJP-led government has pursued what we refer to as Hindu nationalist statecraft - that is, writing the foundational claims of Hindu nationalism into law, and in so doing entrenching religious majoritarianism in the structural workings of the state. This obviously militates in fundamental ways against the secular fabric of India's constitutional order, in particular by abrogating the democratic rights of minority citizens in the country.

The turn towards Hindu nationalist statecraft must be understood as an extension of the strategies that the BJP has resorted to since it first made an appearance in India's political arena in the 1980s, in which parliamentary politics is intrinsically related to extra-legal violence. Indeed, Hindu nationalist statecraft works to compound the vigilante violence that has proliferated in India since Modi first took power in India in 2014. The fact that democratic opposition to these developments - in particular the anti-CAA/NRC protests of 2019 and 2020 - has been curbed by coercive measures simply underscores the perilous nature of the conjuncture that the Indian polity and society are currently confronting.

\section{Glossary}

azaadi:

freedom

Hindu Rashtra:

Hindu state

Hindutva:

Hinduness; ideology of Hindu nationalism

kar sevak:

activist volunteer

rath yatra:

chariot procession

svabhavik patrikriya:

vikas purush:

natural reaction

man of development

yatra:

see rath yatra

\section{Bibliography}

Abraham, D. and Rao, O. (2017). 86\% Killed in cow-related violence since 2010 are Muslim, 97\% attacks after Modi govt came to power. Hindustan Times [online]. 16 July. [Viewed 10 October 2019.] Available from: www.hindustantimes.com/india-news/86-killed-in-cow-related-violence-since2010are-muslims-97-attacks-after-modi-govt-came-to-power/storyw9CYOksvgk9joGSSaXgpLO.html.

Andersen, W. and Damle, S. (2019). Messengers of Hindu Nationalism: How the RSS Reshaped India. London: Hurst and Company.

Basu, A. (2015). Violent Conjunctures in Democratic India. New York: Cambridge University Press.

Baxi, U. (1985). "Taking Suffering Seriously: Social Action Litigation in the Supreme Court of India". Third World Legal Studies 4(6), 107-132.

Berenschot, W. (2011). Riot Politics: Hindu-Muslim Violence and the Indian State. London: Hurst and Company.

Bhuwania, A. (2020). The crisis of legitimacy plaguing the Supreme Court in Modi era is now hidden in plain sight. Scroll [online]. December 1. [Viewed 25 February 2021.] Available from: https:// scroll.in/article/979818/the-crisis-of-legitimacy-plaguing-the-supreme-court-in-modi-era-isnow-hidden-in-plain-sight. 
Bobbio, T. (2012). "Making Gujarat Vibrant: Hindutva, Development and the Rise of Subnationalism in India”. Third World Quarterly 33(4), 657-672.

Bobbio, T. (2013). "Never-ending Modi: Hindutva and Gujarati Neoliberalism as Prelude to All-India Premiership?” Focaal 67, 123-134.

Chatterjee, P. (2019). Kashmir is the test bed for a new model of internal colonialism. The Wire [online]. 28 August. [Viewed 25 February 2021.] Available from: https://thewire.in/government/ kashmir-is-the-test-bed-for-a-new-model-of-internal-colonialism.

Chhibber, M. (2020). Indian courts speak of 'national interest' but they order often in Modi govt's interest. The Print [online]. 12 February. [Viewed 25 February 2021.] Available from: https:// theprint.in/opinion/indian-courts-speak-of-national-interest-but-they-order-often-in-modi-govtsinterest/363859/.

Chowdhury, D. R. (2020). Laws against 'love jihad' are yet another serious attack on India's once secular democracy. Time [online]. November 30. [Viewed 25 February 2021.] Available from: https:// time.com/5915872/love-jihad-india-democracy/.

Daniyal, S. (2020). At a time of acute farmer distress, Karnataka's bovine slaughter bill will make lives even worse. The Scroll [online]. 16 December. [Viewed 25 February 2021.] Available from: https:// scroll.in/article/981255/at-a-time-of-acute-farmer-distress-karnataka-s-bovine-slaughter-bill-willmake-lives-even-worse.

Flåten, L. T. (2016). Hindu Nationalism, History and Identity in India: Narrating a Hindu Past under the BJP. London: Routledge.

Ghassem-Fachandi, P. (2019). "Reflections in the crowd: Delegation, verisimilitude, and the Modi mask". In A. P. Chatterji, T. B. Hansen and C. Jaffrelot, eds., Majoritarian State: How Hindu Nationalism is Changing India. Oxford: Oxford University Press, pp. 83-98.

Gupta, C. (2021). Love taboos: controlling Hindu-Muslim romances. The India Forum [online]. 8 January. [Viewed 25 February 2021.] Available from: www.theindiaforum.in/article/love-laws-makinghindu-muslim-romances-illegitimate.

Hall, S. (1988). The Hard Road to Renewal: Thatcherism and The Crisis of the Left. London: Verso Books.

Hansen, T. B. (1999). The Saffron Wave: Democracy and Hindu Nationalism in Modern India. Princeton: Princeton University Press.

Hasan, Z. (2014). Congress After Indira: Policy, Power, Political Change (1984-2009). Delhi: Oxford University Press.

Jaffrelot, C. (1996). The Hindu Nationalist Movement in India. New York: Columbia University Press.

Jaffrelot, C. (2019). "A de facto ethnic democracy? Obliterating and targeting the other, Hindu vigilantes, and the ethno-state". In A. P. Chatterji, T. B. Hansen and C. Jaffrelot, eds. Majoritarian State: How Hindu Nationalism is Changing India. Oxford: Oxford University Press, pp. 41-68.

Jaffrelot, C. (2020a). Supreme Court's apparent reluctance to question government on consequential issues affects its moral authority. Indian Express [online]. 7 September. [Viewed 25 February 2021.] Available from: https://indianexpress.com/article/opinion/columns/supreme-court-narendra-modigovernment-6585721/.

Jaffrelot, C. (2020b). On 'love jihad', BJP picks up baton from vigilante groups. Police, judicial apparatus have aided this move. Indian Express [online]. 26 November. [Viewed 25 February 2021.] Available from: https://indianexpress.com/article/opinion/columns/love-jihad-law-india-bjp-7067013/.

Jaffrelot, C., and Verniers, G. (2020). "A new party system or a new political system?” Contemporary South Asia 28(2), 141-154

Jakobsen, J. and Nielsen, K. B. (2021). "Bovine Meat, Authoritarian Populism and State Contradictions in Modi's India". Under review.

Kanungo, P. (2019). "Sangh and sarkar: The RSS power centre shifts from Nagpur to New Delhi". In A. P. Chatterji, T. B. Hansen and C. Jaffrelot, eds. Majoritarian State: How Hindu Nationalism is Changing India, Delhi: Oxford University Press, pp. 133-150.

Kaul, N. (2017). "Rise of the political right in India: Hindutva development mix, Modi myth, and dualities". Journal of Labour and Society 20(4), 523-548.

Lalchandani, N. (2020). Up to 10-year jail for cow slaughter in UP. Times of India [online]. 10 June. [Viewed 25 February 2021.] Available from: https://timesofindia.indiatimes.com/india/up-to-10year-jail-for-cow-slaughter-in-up/articleshow/76293141.cms.

Müller, J.-W. (2016). What Is Populism? Philadelphia: University of Pennsylvania Press.

Nilsen, A. G. (2019). Onward march of Hindu nationalism. Mail and Guardian [online]. 15 November. [Viewed 25 February 2021.] Available from: https://mg.co.za/article/2019-11-15-00-the-onwardmarch-of-hindu-nationalism/. 
Nilsen, A. G. (2020). India's breaking point. Polis Project [online]. January 11. [Viewed 25 February 2021.] Available from: https://thepolisproject.com/indias-breaking-point/\#.XzuxoElS_OQ.

Nilsen, A. G. (2021a). "From inclusive neoliberalism to authoritarian populism: Trajectories of change in the world's largest democracy". In M. Ray, ed. State of Democracy: Essays on the Life and Politics of Contemporary India. Delhi: Primus Books.

Nilsen, A. G. (2021b). "India's trajectories of change, 2004-2019”. In V. Satgar and M. Williams, eds. Democratic Marxism Volume 6-Capitalism Against Democracy, Johannesburg: Wits University Press.

Nilsen, A. G., Nielsen, K. B. and Vaidya, A. P. (2022). "Theorizing Law, Social Movements and State Formation in India", Comparative Studies in South Asia, Africa and the Middle East.

Patel, R. (2018). Islamophobia Gastronomica - on the food police, rural populism and killing. OpenIndia [online]. 26 February. [Viewed 25 February 2021.] Available from: www.opendemocracy.net/ openIndia/raj-patel/islamophobia-gastronomica-on-food-police-rural-populism-and-killing.

Ramdas, S. (2017). The beef ban effect: Stray cattle, broken markets and boom time for buffaloes. The Wire [online]. 6 April. [Viewed 25 February 2021.] Available from: https://thewire.in/politics/ beef-ban-cattle-market.

Ramdas, S. (2020). Will Karnataka's new bill sound the death knell for its cattle wealth? The Leaflet [online]. 15 December. [Viewed 25 February 2021.] Available from: www.theleaflet.in/will-karnatakas-newbill-sound-the-death-knell-for-its-cattle-wealth/\#.

Sebastian, M. (2019). How has the Supreme Court fared during the Modi years? The Wire [online]. 12 April. [Viewed 25 February 2021.] Available from: https://thewire.in/law/supreme-court-modi-years.

Shani, O. (2007). Communalism, Caste and Hindu Nationalism: The Violence in Gujarat. Cambridge: Cambridge University Press.

Sud, N. (2012). Liberalization, Hindu Nationalism, and the State: A Biography of Gujarat. New Delhi: Oxford University Press.

Sud, N. (2020). "The actual Gujarat model: Authoritarianism, capitalism, Hindu nationalism and populism in the time of Modi". Journal of Contemporary Asia, pp. 1-25. DOI: 10.1080/00472336.2020.1846205.

Vaishnav, M. and Hintson, J. (2019). The dawn of India's fourth party system. Carnegie Endowment [online]. September 5. [Viewed 25 February 2021.] Available from: https://carnegieendowment.org/2019/09/ 05/dawn-of-india-s-fourth-party-system-pub-79759.

Vanaik, A. (2017). The Rise of Hindu Authoritarianism: Secular Claims, Communal Realities. London: Verso Books.

Zargar, H. (2020a). Modi advances settler colonial project in Kashmir. New Frame [online]. 15 June. [Viewed 25 February 2021.] Available from: www.newframe.com/modi-advances-settler-colonialproject-in-kashmir/.

Zargar, H. (2020b). Modi regime moves to dispossess Kashmiris of land. New Frame [online]. 17 November. [Viewed 25 February 2021.] Available from: www.newframe.com/modi-regime-moves-to-dispossesskashmiris-of-land/.

Zargar, H. (2020c). The 'love jihad' returns to haunt Muslims in India. New Frame [online]. 15 December. [Viewed 25 February 2021.] Available from: www.newframe.com/the-love-jihad-returns-to-hauntmuslims-in-india/. 